\title{
11
}

\section{The FinTech Industry: Crowdfunding in Context}

\author{
Paul Griffiths
}

\section{Introduction}

The last three decades of the twentieth century witnessed the adoption of information and communications technology (ICT) by business corporations at an increasing rate and banks were leaders and trendsetters in this process. However, this leadership role of banking in the development of corporate ICT was lost in the second half of the first decade of this millennium. This chapter intends to shed light on the process that led to this. In so doing, it addresses the questions: Why did FinTech emerge as an industrial sector, independent of banking?

The author is strongly connected to the world of ICT transformation and of banking as an information intensive industry. He entered the business world as a young graduate during the mainframe-based, bespoke systems age; he then oriented his career towards management consulting, where he carried out and led technology-enabled business transformation

\section{P. Griffiths $(\bowtie)$}

EM Normandie Business School, Métis Lab, Oxford, UK

e-mail:pgriffiths@em-normandie.co.uk 
projects in the enterprise resource planning (ERP) era and the customer relationship management $(\mathrm{CRM})$ and e-commerce solutions era; he replaced legacy core-banking systems by more modern client-server platform ones. On the academic side, he went back to university and enrolled on a doctoral programme that he researched into strategy-technology alignment in banks from which he graduated in 2005 . He then became a full time academic and for the last three years has been researching the industrial organization of the FinTech sector. So, it is from this broad background that bridges across the practitioner and academic worlds in banking and technology that he sets out to address the above questions.

The rest of this chapter is organized in the following way. Section "Twentieth Century: ICT Emerging and Evolution" will give an overview, based on the author's professional experience, of the evolution of ICT in the last three decades of the twentieth century. From the specific perspective of banks, it will show that the financial sector in general, and banking in particular, was a driver of the ICT evolution during that period, until the mid-2000s. Section "Advent of the Tipping Point: Why Did Banks Lose Control?” will, based on current literature, identify three root-causes for banks to have lost control over the ICT agenda in the financial sector. In having lost control of the evolution of ICT, Section "A New Industrial Sector: The Emerging of FinTech" will give a framework to understand how the FinTech sector is structured based on a classification of the players according to the functional services they offer and the types of technology they apply. It will emphasize the role of crowdfunding in this landscape. Section "Discussion" will offer a discussion on the findings, and Section "Conclusions" will draw some conclusions.

\section{Twentieth Century: ICT Emerging and Evolution}

The last three decades of the twentieth century witnessed the adoption of information and communications technology (ICT) by business corporations at an increasing rate. During the 1970s and 1980s it was large systems developed and running on mainframe computers, with bespoke 
applications of narrow functional scope and weak integration with other functional applications. ICT was essentially about number-crunching large volumes of flat files, initially fed in by perforated cards and later in the period by magnetic tapes and discs. It was a domain restricted to the largest corporations, prominent amongst them the big banks, government institutions and universities. Systems were all corporate and managed by large IT departments with battalions of in-house programmers, analysts and systems engineers complemented by professional staff belonging to the large systems companies (that later called themselves 'integrators') such as IBM, Honeywell-Bull, ICL, Unysis. The technology platforms on which these corporate applications were developed were proprietary, with no convertibility from one vendor's platform to another vendor's: Client lock-in was the name of the game.

Democratization of ICT and its access to the smaller corporations and companies came in the mid-to-late 1980s and early 1990s with the advent of the mini-computer, the table-top personal computer, local area networks, handheld devices and, very importantly, the relational database. Democratization turned into revolution with the access to, and popularization of, the Internet.

The until then reigning mainframe computer and its centralized architecture ceded part of its domain to the distributed client-server architecture. The mainframe did not completely go away as those organizations who had them tended to keep the mainframe as database server due to its low cost per transaction for large volumes of transactions.

In parallel with client-server a significant change in the 1990s was the advent of the enterprise resource planning (ERP) systems with a new key player that with time became the dominant player in the corporate applications world, breaking the until then hegemony of the Anglo-Saxon companies: SAP from Waldorf, Germany. Being the four founders of SAP ex-IBM engineers, the first versions of their ERP ran on mainframes, but they really took off with their first client-server version that they called R/3. There were competing providers such as Oracle (with its Financials), JDEdwards, and PeopleSoft. This wave responded to a significant change in philosophy and the name of the game now had two dimensions: (a) it was all about packaged solutions, that is solutions that did not need code developed from scratch for each corporation, but that 
would be standard with the possibility of configuring parameters for limited adaptation to each company; and (b) integration was dominant over best-of-breed solutions, that is that now it was more important to have integration across functional applications than to have the best individual and isolated application.

Integrated packaged solutions brought with them another significant change: the concept of 'leading practices' in business processes. While the bespoke systems of the mainframe era were modelled in line with the processes of each company, in the ERP era the company would adapt its processes to the leading practices in-built in the solution. The implications of this is that the implementation of an ERP system would lead to significant changes in processes that, in turn, radically changed people's jobs. Thus, change management became an important component of implementation projects, with a focus on stakeholder management and training of people in entire processes, not just their specific task in a large process as was the case before.

Another change that came with the ERP wave is how projects were organized. The configuration of a systems project team was no longer a team of highly technical analysts and programmers, but people who were versed in business processes. The bulk of the work was not in coding but in parameter configuration and change management activities. So, the project teams were integrated mainly by non-technical systems people. ERP projects were not referred to as systems or technology projects anymore, but as business transformation projects enabled by technology.

Ripples of ERP in 1991-1993 became waves in 1994-1998 and turned into tsunamis approaching 2000 and the generalized policy of implementing 'vanilla' ERPs to sort the $\mathrm{Y} 2 \mathrm{~K}$ problem (this term was coined by Gartner Group and refers to the fact that the early mainframe systems had only two-digits for the year in dates, so it was suspected that they would all fail with the advent of the new millennium). With the advent and establishment of ERPs, came the reduction in the size of the IT departments in corporations. In effect, what adopting and implementing ERP meant was that the development of new functionalities to adapt to changes in the legal and tax environment, or to the need for new functionalities, was outsourced to the ERP vendors. 
Of course, ERP were not the panacea that appears at first sight. Significant amount of coding to ensure integration with legacy systems or vertical industry-specific applications were still necessary. Although 'big bang' projects were highly promoted, common sense and risk management led to many projects being piloted and phased in, which meant that temporary interfaces had to be developed. And although the ERP vendors did produce their solutions with specific flavours for different industries, this was still not enough and corporations demanded having some of their vertical functionality developed outside of the ERP. For example, SAP achieved a highly competent footprint in the consumer packaged goods (CPG) and in the utilities industries, but never managed to produce convincing solutions for the core-banking functionalities despite having invested heavily in its solution for that sector. In other words, coding and development effort for integration did not entirely go away.

After the ERP binge running up to $\mathrm{Y} 2 \mathrm{~K}$ came the hangover in the form of a relative slowdown in the ERP market, but that did not stop the corporate-systems business as a whole. At around the time that ERP slowed down e-commerce and client relationship management (CRM) solutions emerged with force. E-commerce was the hottest product but it was severely impacted by $9 / 11$ and the implosion of dot.com, recovering afterwards but growing at a more moderate pace.

With the slowdown of the ERP market and of the global economy after 9/11, came a consolidation within the corporate ICT solutions industry. SAP expanded its functionality into CRM, e-commerce and business intelligence through internal developments but later broke this tradition by entering the acquisitions path. Oracle, on the other hand, acquired PeopleSoft, Siebel (the leading CRM provider), JDEdwards, and many others, with significant pains in converting all these independent applications into a coherent, seamless offering to its clients. Oracle also moved into the hardware space by acquiring SUN Microsystems and SAP moved into Oracle's traditional realm, the database layer, through acquisition, too. Oracle articulated the concept of 'stack', from hardware to enterprise application, through operating systems, databases, integration layers and others. Oracle publicized itself as being able to offer the whole stack or just some of the layers. 
The strong narrative of ERP vendors in terms of the importance of integration started weakening with the advent of intelligent middleware communications platforms that made unnecessary the dreaded point-topoint, or one-to-one, interface development. The nightmarish spaghettistyle interfaces that haunted CIOs and kept them awake at night, could now be substituted by simpler to understand middleware layers into which applications could easily be plugged in. Another highly significant concept that was materializing and coming of age at the turn of the century was the API (application programming interface-term that was coined decades before by Cotton and Greatorex 1968), a set of subroutine definitions, communications protocols and tools for building software. As will be seen in Section "Discussion", APIs would play an important role in the FinTech world.

The prior paragraphs give an overview of how corporate ICT in general developed from the 1970s to the early 2000s. The effect on business transformation of the adoption of ICT was highly significant, but nowhere more than in banking. Banking is an information-intensive industry, by which it is meant that differentiation comes exclusively from their intellectual capital and information or, in other words, their people, processes, relationships, and technology (Clayton and Waldron 2003; Griffiths 2003, 2005; McKeen and Smith 1996; OECD 2003, pp. 65-66). ${ }^{1}$

Driven by this dependence on information, banks played very much of a leading role in adoption and development of ICT, and the trajectory they followed differed from the mainstream CPG, retail, industrial products, and utilities corporations. Banks were clearly ahead of the pack in the early phase of that period, that of the bespoke systems running on mainframe computers. They were so heavily vested in those technologies and had such high numbers of transactions compared to the other industries, that they could not make the business case for moving to clientserver. This, together with the fact that banking processes and applications had become highly sophisticated and business critical at an extreme, disincentivized the ERP vendors to develop vertical solutions for banking in the early days of ERP. Eventually SAP did propose a banking-solution, but its adoption was disappointingly slow and hardly ever with an endto-end footprint but limited to fragmented pieces of the business. 
Essentially, the largest banks are trapped, to this day, in their legacy systems.

Indeed, banks have adopted standard packaged solutions in many parts of their business, particularly the highly technical middle office, but the back office remains on the legacy systems. That is not to say that there have not been any client-server solutions for banks, but the more successful ones have been developed by specialized companies and not the leading ERP vendors. For example, Citi co-developed a client-server core banking system with a company called i-Flex in India, to implement in its smaller operations around the world (it later divested from i-Flex and a few years later i-Flex was absorbed by Oracle). So, essentially, banks did not participate in the ERP part of the prior narrative.

Notwithstanding their attachment to the legacy mainframe systems, banks did make some memorable breakthroughs, of which the ATM is a notable example. The generalization of ATMs in the 1980s enabled banks to give $24 \times 7$ service and significantly lower their banking transaction costs. This led the self-service kiosk technology that is still in the process of being adopted by other corporations in most other industries and government.

The ATM was followed by the waves of phone banking, home banking, and Internet banking. They all had in common pushing their clients out of the branch office and lowering further the costs of banking transactions and brought with them the need for omni-channel, that is the need to show the same face to the client independently of what channel the client chose to interact with her bank. So, the big banks that had departed from mainstream in the ERP age, took leadership again in the CRM phase. With this came the transformation of the banking branch office, that until the 1990s was a mini-bank in its own right with all functionalities in the branch. From the turn of the century banks took all the back-office and middle-office functionalities (e.g., bookkeeping and accounting, credit scoring, loan origination) from the branch to the head office, and most of the transactional activity out of the branch to remote channels. The branch office became far smaller and focused on valueadded client services.

This narrative brings us to the mid-2000s when a tipping-point with several fronts was reached in the ICT world as will be developed in later 
sections. As has briefly been outlined in this section, ICT in business and government went from a rarity in the 1970 s to complete infiltration and dissemination in the early 2000s. What this story is telling us is that during this period of study the world, or at least what we generally refer to as the Western world, almost unperceptively migrated from an industrial economy of predominantly tangible assets, to a knowledge one where intangible ones overwhelmingly predominate over the tangible. This is a new era where the application of ICT radically changed, and where banks lost their grip on its development.

The importance that ICT took on in the business world in general, but especially so in such an information-intensive sector as is banking, makes the research question stated in Section "Introduction" of the utmost relevance both to the practitioner and to the academic world. The process through which this happened is described in the next section.

\section{Advent of the Tipping Point: Why Did Banks Lose Control?}

\section{Overview}

A thorough review of the literature on the emerging of the FinTech sector was carried out - the emphasis was put on academic papers from 2012 onwards, as it is thought that before then would be too close to the events for clarity and that it has been found by Zavolokina et al. (2016, p. 9, fig. 1) that article publication numbers started growing that year. Based on that search this section identifies three root-causes that, although unrelated to each other, happened to coincide in time and lead banks to have lost control over the ICT agenda in the financial sector. The narrative in Section "Twentieth Century: ICT Emerging and Evolution" brings us to the mid-2000s and it announces that around that time several major events happened in the banking, the ICT world and society in general that led to the emerging of a new industrial sector that we nowadays call FinTech as a contraction of financial technology. The Basel Committee on Banking Supervision (BCBS) defines FinTech quite broadly as 
[t]echnologically enabled financial innovation that could result in new business models, applications, processes or products with an associated material effect on financial markets and institutions and the provision of financial services. (Claessens et al. 2018; Palazzeschi 2018)

So for BCBS FinTech is a form of innovation, but a very broad one at that, as it includes business models, applications, processes, or products. Dorfleitner et al. (2017) while admitting that there is no universally accepted definition of FinTech, take a more cautious approach and refrain from proposing a definition based on that while accepting that most companies in the FinTech sector share certain features, there are always enough exceptions to render them inadequate for producing a general definition. They opt to give a summary description of the different service domains of FinTechs, that they group in four: (a) financing, (b) asset management, (c) payments (in which they include cryptocurrencies), and (d) other FinTechs. The latter includes a hotchpotch of things such as insurance; search engines and comparison sites; technology, IT and infrastructure; plus 'other FinTechs'. Both approaches have limitation: BCBS stay at a conceptual level, and Dorfleitner et al. (2017) are far too broad and encompassing, which unsurprisingly gives place to so many exceptions.

In this chapter we will overcome those problems and propose and adopt a definition. We will overcome the BCBS limitation by defining FinTech as a company/organization, and we will narrow the service offering domain. We will limit the services to banking services, that is services where the core competence is managing credit risk, market risk, or banking operational risk. So, by FinTech in this chapter we understand not the technology itself, but a digital technology-enabled entrepreneurial initiative that offers services to clients that would traditionally be considered within the domain of banks; or that are an innovative service in the natural business domain of banks; or that help banks develop their back-office processes.

So, returning to the research question-Why did Fin Tech emerge as an industrial sector, independent of banking? - and to focus the mind we will address it by responding to four subquestions: 
- What caused banks to lose leadership in the development of corporate ICT systems?

- What enabled the FinTech sector to emerge with such vitality in a business dominated by behemoths?

- What encouraged entrepreneurs to move into the service domain traditionally served by banks?

- How is the FinTech industry organized and where does crowdfunding fit in?

Arner et al. (2017) divide the co-evolution of finance and technology into three stages, namely:

(a) The analogous age prior to the late twentieth century,

(b) the digitalization era that goes from the late twentieth century until 2008, and

(c) the diverging era with the advent of new financial providers based on advanced technologies.

As is mostly the case, there is not a single cause for the advent of the tipping point that moved the evolution of finance and technology into the diverging era. This research identifies three unrelated causes that happened in the 2007-2008 point in time; it is quite probable that none of these causes alone would have caused such a disruption, but their coincidence in time enabled them to feed into each other and cause havoc in the banking industry. The first is the global financial crisis known as the Great Recession that is generally accepted as having been caused by the banking system and its greed in the mortgage segment. The second is several nearly simultaneous major breakthroughs in the technology sector that led to a drastic drop in entry barriers to the banking services sector. And finally, significant social changes with the coming of age of the millennial generation and their growing role in the business world and in relationship to banking. The rest of this section will flesh out these three causes. 


\section{The Effect of the Great Recession}

The 2007-2008 recession put banks in the US, the UK, and several countries on the European continent at the brink of collapse leading to systemic failure which, in turn, led banking authorities in those markets to bail them out with public funds. Subsequent investigation into the events detected that banks accelerated their growth by taking on excessive risk that they partially transferred to other organizations through financial engineering devises concocted by their investment banking arms. In conjunction with this, the population became extremely critical of banks and there was general distrust in these institutions. These three factors led national authorities to react, and in many cases over-react, with the result of far more stringent banking regulations that caused great regulatory challenges to the banks (European Central Bank 2016; Haddad and Hornuf 2019; Kotarba 2016). These more stringent regulations worked in two directions (see Fig. 11.1).

The first was in the sense of demanding banks to significantly increase their regulatory capital so that never again would they need to be rescued with public money. Because as a result of the crisis capital was costly to acquire by banks, they reacted by reducing the denominator of the capital adequacy ratio, that is by reducing their exposure to risk. They did this by pruning those clients of higher-risk profile, and by letting go the less

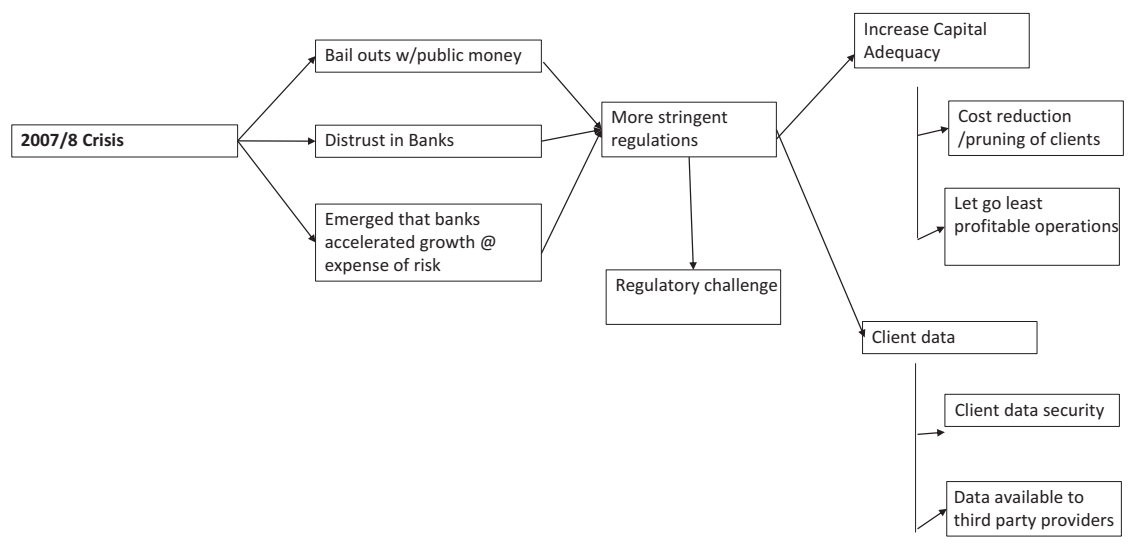

Fig. 11.1 The effect of the 2007-2008 crisis 
profitable operations (e.g., certain products and geographic markets). The resulting reduction in scale in turn led them to embark on cost reduction initiatives (European Central Bank 2016; Kotarba 2016).

The other way in which more stringent regulations worked was related to client data. On the one hand the authorities put emphasis on client data security, and on the other hand bank regulators demanded that client data be made available to third-party providers in order to break the oligopoly of incumbent banks and increase competition in banking service (European Commission 2014, 2015; Tammas-Hastings 2017).

\section{The Effect of Major Technological Breakthroughs}

At the time the banks focused all their senses inside to cope with the regulatory changes that came because of the crisis, three key technology phenomena were happening. The first is incremental and refers to the continuing of Moore's law that translated into lower prices and thus giving more and more people access to devices (Lundstrom 2003; Waldrop 2016).

The second was the swift coming of age of Cloud computing with a change in mind-frame in the business community in the sense that moving from on-premise applications to cloud ones did not bring extra risks in terms of data security, and that adopting an on-demand model for technology appropriation had significant operational and balance sheet advantages (Ambrust et al. 2010; Rimal et al. 2009).

The third phenomenon was surely disruptive and is the advent of the first i-Phone and from there all the forms of smartphones that came after it. Moreover, the smartphone had the effect of enabling the development of social networks and, thus, the side effect of the advent of the data tsunami usually understated as Big Data (Barkhuus and Polichar 2011; Lee and Shin 2018; Smolan and Erwitt 2012).

These three phenomena had effect on what was to be the emerging FinTech sector, and on incumbent banks. The effects on these two groups initially developed quite independently of each other, but as will be seen opportunities for cross-fertilization emerged in later stages (EY 2018, p. 28; Gai et al. 2018; Lee and Shin 2018). 
Looking at the FinTech sector first, it is found that the conjunction of the three technological phenomena had the effect of both lowering entry barriers for small new players to offer components of financial services and giving many more people access to devices and thus become potential clients for these new entrants to the financial services market offering. As opposed to entrepreneurial technology-based start-ups in other sectors, in general these new players in the FinTech sector did not have cash to burn at outrageous rates, so they developed two characteristics. On the one hand they are limited in the scope of their service, and on the other they take incremental opportunities in relatively mature markets that offer them quick cash-flow. These two characteristics translate into them focusing on niche but profitable parts of the incumbent banks' business, causing strong reaction from the banks who denounce them as avoiding regulations to take the icing of their cake (Lacasse et al. 2016).

The conjunction of taking the more profitable pieces of the banks' business and being able to serve many more people who were then possessing digital devices, converted into great opportunities for the emerging FinTechs. But their increasing visibility and the protests of the incumbent bankers led banking regulators to observe this new sector and extend at least part of the regulations to them.

From the perspective of incumbent banks, these three technological phenomena and their derivations (i.e., social networks and Big Data) had a significant impact on their own operations. Bank clients were demanding new channels such as mobile and generating massive data flows that offered significant potential if properly exploited. However, they also posed unsurmountable challenges in terms of cybersecurity, of data analytics issues and of data visualization complexities to incumbent banks that were constrained by their legacy systems as described above. This led the banks to start seeing FinTechs as potential enablers for their own processes in this new era of financial services (EY 2018; Gai et al. 2018).

Particularly on continental Europe where FinTechs were being funded more by banks than venture capital (Lee and Shin 2018), risk management challenges emerged quickly and were addressed by regulators which erected barriers for FinTechs to operate as independent client-facing service providers, but opened opportunities in the banks that were funding them. So, in general, the antagonistic atmosphere between incumbent 


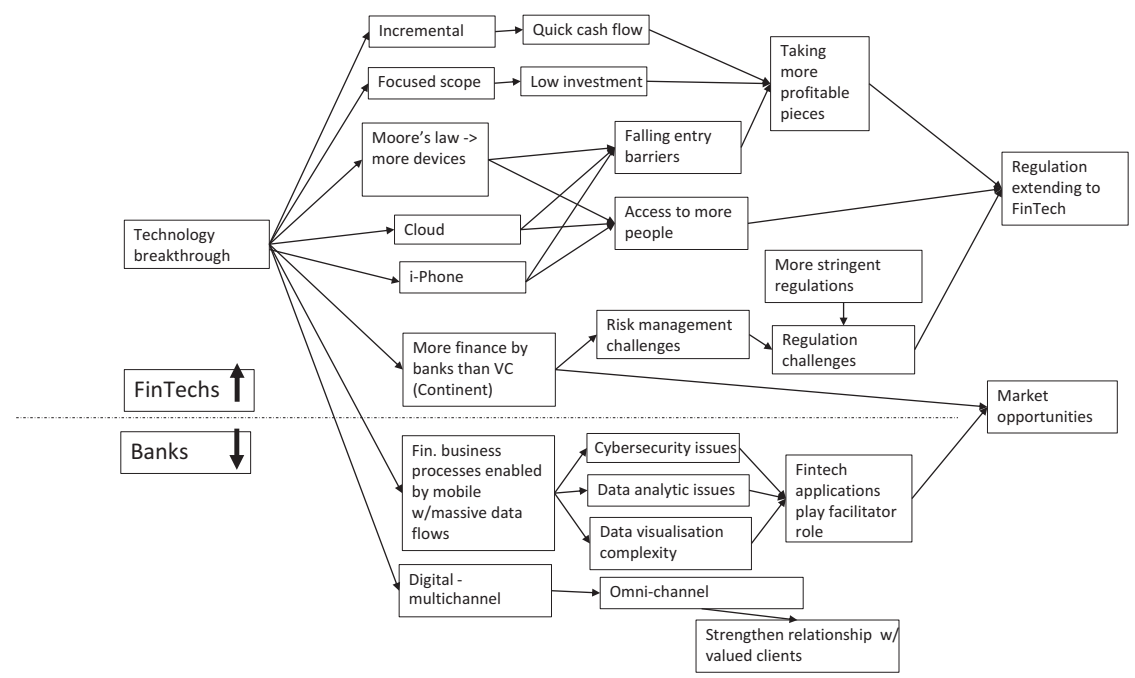

Fig. 11.2 The effect of major technological breakthroughs on FinTech and banks

banks and FinTechs that prevailed in the early post-2008 years gave way to a more collaborative spirit between both sectors. This effect of the technological breakthroughs is depicted graphically in Fig. 11.2.

\section{The Effect of Social Changes}

At the time of the financial crisis and the advent of the technological phenomena described above, the business world was going through major social transformations in terms of power as depicted by Naim (2013), of the changes in mindset that came with Generation Y taking a growing role in the workforce and of the advent of social entrepreneurs and entrepreneurship.

The Generation Y are avid adopters of mobile banking as long as it is easy to use and it poses no excessive risks in terms of data security. Both these conditions were hard to meet for incumbent bankers due to their legacy platforms, but straight forward for the FinTechs. On the other hand, due to the capital constraints mentioned above banks put effort into developing CRM processes and solutions that enabled them to 
strengthen their relationship with their 'valued' (i.e., the older more affluent) customers, and let go their less profitable and higher risk ones, as the Generation Y were seen to be. This opened a segment of great potential to the FinTechs (Boonsiritomachai and Pitchayadejanant 2017; Lee and Shin 2018).

In parallel with the above and especially in the Anglo-Saxon world, there emerged a new breed of what were to be called social entrepreneurs whose projects did not pursue a predominantly financial objective and thus were unfit to be assessed in terms of the banks' traditional credit scoring criteria. This new breed of entrepreneurs resort to alternative finance sources such as crowdfunding so became another market opportunity for FinTechs (Kotarba 2016).

On continental Europe it was found that while people do not trust banks much more than in the Anglo-Saxon world, they have less incentive to leave their banks and trust FinTechs even less than banks. So that becomes a barrier for FinTechs on the continent.

The effects of social changes are depicted and summarized in Fig. 11.3.

As a result of these three external forces (i.e., the Great Recession and subsequent regulatory changes, the technology breakthroughs, and the social changes) acting nearly simultaneously, banks lost control of the

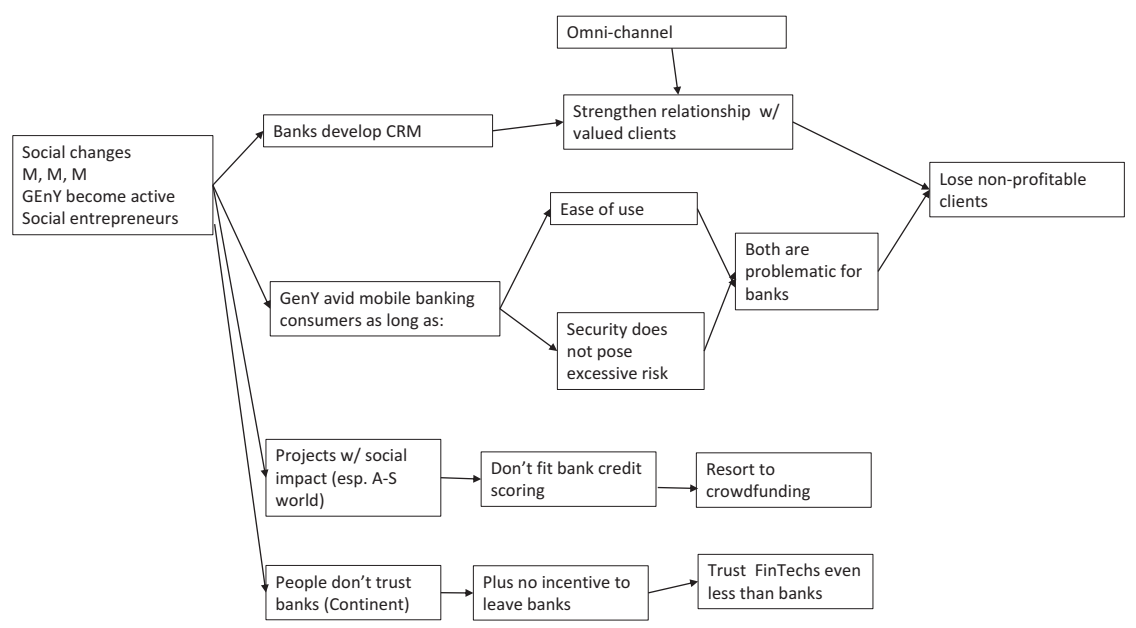

Fig. 11.3 Effects of social changes on banks and FinTech 
evolution of ICT and left the door wide open for technology entrepreneurs to set up independently and eat away at the icing of their cake. The next section gives an overview of the industrial organization of this new sector.

\section{A New Industrial Sector: The Emerging of FinTech}

As mentioned above the FinTech sector is quite different from other technology-driven entrepreneurial or start-up sectors in the sense that it did not access massive funding and therefore its companies had to be focused in terms of service scope, and it did not produce great new markets but rather served extant markets that were until then poorly or underserved by banks. While, due to the latter, initially the relationship between traditional banks and FinTechs was notoriously antagonistic, with the passage of time banks realized that their constraints from legacy systems would obstruct them entering the digital era, so started to see FinTechs as possible collaborators to help overcome those barriers. This is particularly so in the data-oriented, security and privacy, and compliance spaces (Duan and Da 2012; Gai et al. 2018; Roumani et al. 2016).

Growth of the FinTech sector in terms of investment is literally exponential, going from $\$ 1.8$ billion in 2010 to $\$ 19$ billion in 2015 according to some sources (Citi 2016 cited by Leong et al. 2017) or from $\$ 1.5$ billion in 2010 to $\$ 22$ billion in 2015 according to others (Shuttlewood et al. 2016) and there are indications of steep growth in 2016 (Lee and Shin 2018). Within this context, seven banking-service areas emerge as the domains where FinTechs carry out their offering. These are: alternative finance, transactions, investment markets, banking back office, financial inclusion, cryptocurrencies, and business partner integration.

Alternative finance refers to services that supersede the traditional lending function of banks. They include personal finance, consumer finance, small and medium enterprise lending, and prominent in this category is crowdfunding in its four formats: reward-based, donation-based, equity-based and loan-based. Examples of reward-based crowdfunding companies include Kickstarter, Indiegogo, CrowdFunder, and RocketHub; of donation-based 
are GoFundMe, GiveForward, and FirstGiving; of equity-based crowdfunding companies are AngelList, Early Shares, and Crowdcube; finally, of loanbased crowdfunding companies are Funding Circle and Cumplo (Lee and Shin 2018; Shneor and Munim 2019 citing Ziegler et al. 2018).

Transactions refers to one of the most active areas of FinTech as are payments and remittances. These two areas were traditionally controlled by banks but are now giving way-in the case of payments by offering layers of service overlaying those of traditional banks and biting away at parts of the fees that banks charge in this space. In the case of remittances, it is about offering channels that circumvent bank services and fees altogether (Lee and Shin 2018).

Investment markets include services such as equity financing, retail investment, institutional investment, fund management and crowdfunding as an opportunity for investing (Lee and Shin 2018; Shneor and Munim 2019).

Banking back office is about FinTechs supplying banks agile services such as banking infrastructure, financial security services, identity verification, compliance, business tools, financial research, and energy efficiency in regard to achieving green finance. Prominent amongst these are RegTech, a flavour of FinTech aimed at helping banks comply with the demands of regulators and assist banking supervisors in keeping track of the banks under their watch (Gai et al. 2018; Puschmann 2017; TammasHastings 2017).

Financial inclusion means reaching out to the unbanked and offering financial services at an extremely low cost and fill a gap that banks have never tackled, with well thought through and low-cost service offerings; micro-finance is prominent amongst this category (Lacasse et al. 2016).

Cryptocurrencies emerged as an initiative to circumvent banks altogether in the payments space but have not materialized as such; up to now they have served more as investment than payment instruments, and with doubtful outcomes at that. However, the distributed ledger technology that underlies them could be of application in many other areas such as trading and 'smart contracts' (Chen 2018; Hawlitschek et al. 2018).

Business partner integration is about FinTech offering services that bridge across the traditional offerings of banks and of other sectors with large business-to-consumer operations, such as telecommunications, 
retailers and airlines (Kumar et al. 2006; Rosingh et al. 2001; Schmitt and Gautam 2016).

To deliver these services FinTechs will apply one or multiple emerging technologies such as the DANCE acronym (Data, Algorithm, Networks, Cloud, Exponential) proposed by McAfee and Brynjolfsson (2017) and others including mobile, distributed ledgers, bioinformatics and behavioural biometrics, robots, all-in-one smartcards, and others.

It is helpful to understand the industry to present this in the form of a double entry table and map the FinTech companies onto the cells of this matrix (see Table 11.1).

The rest of the chapters in this book will develop the contents that will fit into the columns under alternative finance and investment markets of this framework. Those are the two service domains in the FinTech I/O framework where crowdfunding plays a key role. In the first case in its funding role, and in the second in its investment opportunities role. Just as an example of how this works, Table 11.2 reproduces the contents of one cell in this framework: The cell corresponding to Alternative Finance as a service domain, and data analytics and the exploiting of Big Data as a predominant enabling technology for those services.

It should be noted that in the Table 11.2 there are the four kinds of crowdfunding companies described above, but there are also other companies such as Touch Bank, which is a retail bank, or Retail Capital, which lends through partnership with banks, and do not conform to the crowdfunding principles but nevertheless are FinTechs in the alternative finance space.

With all this information in mind, the next section will extract some insights into how the FinTech sector emerged and evolved, and it will address the research question.

\section{Discussion}

Many interesting insights emerge from this analysis of the FinTech sector, of which four will be mentioned in this section. The first is that technological breakthroughs are all important but are only a necessary but not a sufficient condition for the advent of FinTech. Cultural-based influences 


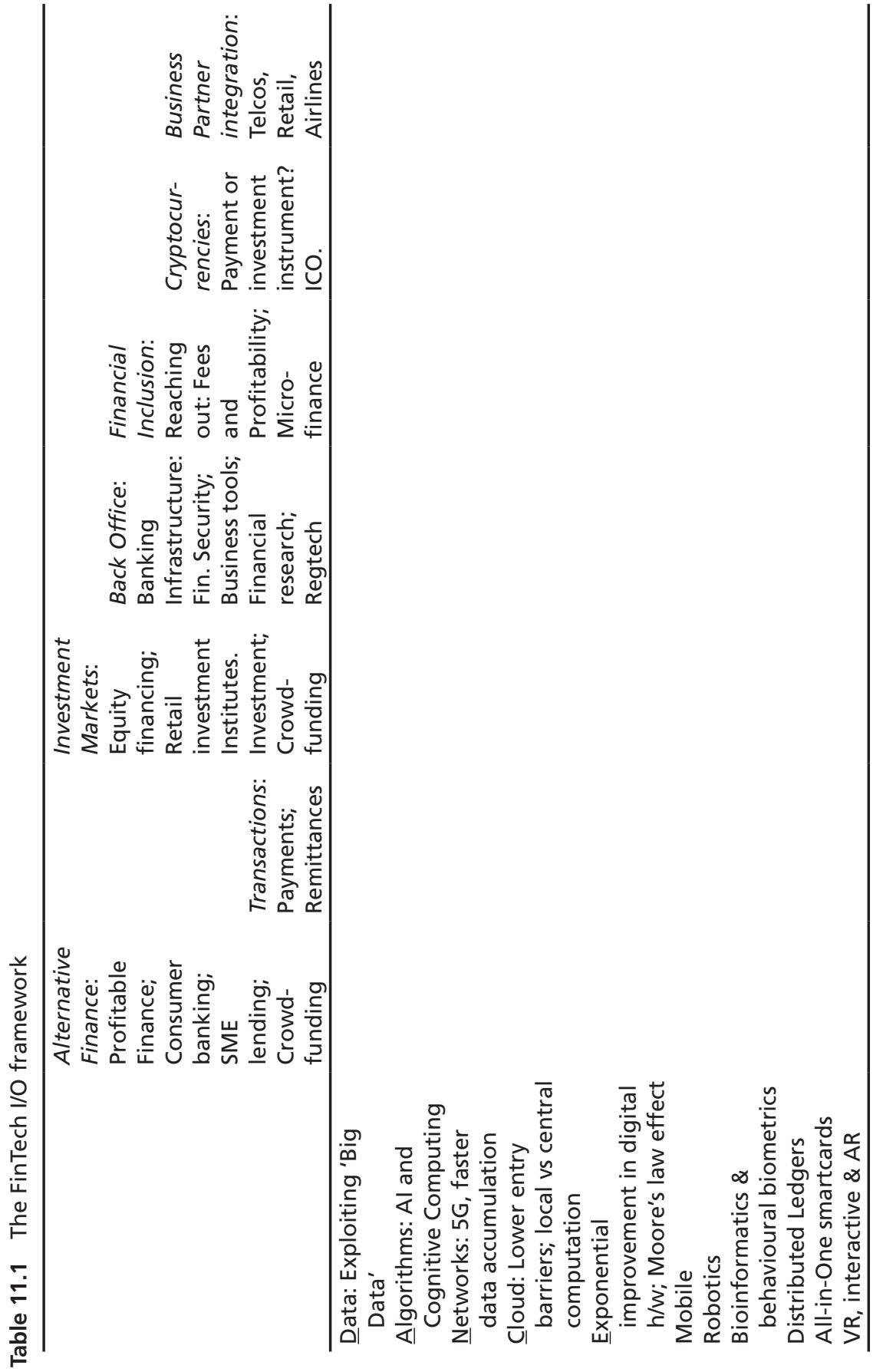


Table 11.2 Sample from the repository of FinTechs

\begin{tabular}{|c|c|c|c|c|}
\hline $\begin{array}{l}\text { Company's } \\
\text { name }\end{array}$ & Country & Activity & Notes & Website \\
\hline Lendingkart & India & $\begin{array}{l}\text { Business loan } \\
\text { for small } \\
\text { business }\end{array}$ & $\begin{array}{l}\text { Co-lending with } \\
\text { banks }\end{array}$ & $\begin{array}{l}\text { www.lendingkart. } \\
\text { com }\end{array}$ \\
\hline KredX & India & $\begin{array}{l}\text { Business loan } \\
\text { for small- and } \\
\text { medium-sized } \\
\text { businesses }\end{array}$ & $\begin{array}{l}\text { Investors/applied } \\
\text { for an } \\
\text { Non-Banking } \\
\text { Financial } \\
\text { Company (NBFC) } \\
\text { licence }\end{array}$ & www.kredx.com \\
\hline Wefinance & USA & $\begin{array}{l}\text { Lending to } \\
\text { particular by } \\
\text { funding from } \\
\text { particulars }\end{array}$ & & $\begin{array}{l}\text { www.wefinance. } \\
\text { com }\end{array}$ \\
\hline Upstart & USA & $\begin{array}{l}\text { Bring together } \\
\text { high-potential } \\
\text { borrowers and } \\
\text { investors }\end{array}$ & $\begin{array}{l}\text { Calculate credit } \\
\text { score based on } \\
\text { borrower's } \\
\text { background }\end{array}$ & www.upstart.com \\
\hline SoFi & USA & $\begin{array}{l}\text { P2P lending for } \\
\text { students }\end{array}$ & & www.sofi.com \\
\hline $\begin{array}{l}\text { Rocket } \\
\text { Mortgage }\end{array}$ & USA & $\begin{array}{l}\text { Loans and } \\
\text { mortgages }\end{array}$ & $\begin{array}{l}\text { Focus on } \\
\text { millennials }\end{array}$ & $\begin{array}{l}\text { www. } \\
\text { rocketmortgage. } \\
\text { com }\end{array}$ \\
\hline C2fo & UK & $\begin{array}{l}\text { Short-term } \\
\text { loans }\end{array}$ & & C2fo.com \\
\hline Zopa & UK & P2P lending & $\begin{array}{l}\text { Founded in } 2005 \text {, } \\
\text { one of the first } \\
\text { sites directly } \\
\text { bringing } \\
\text { together } \\
\text { borrowers and } \\
\text { savers, cutting } \\
\text { out financial } \\
\text { institutions from } \\
\text { the lending } \\
\text { process (NYT) }\end{array}$ & www.zopa.com \\
\hline Touch bank & Russia & Retail banking & $\begin{array}{l}\text { Online credits, } \\
\text { loans, card, } \\
\text { account } \\
\text { management } \\
\text { without } \\
\text { paperwork, } \\
\text { saving } \\
\text { management }\end{array}$ & $\begin{array}{l}\text { www.touchbank. } \\
\text { com }\end{array}$ \\
\hline
\end{tabular}


Table 11.2 (continued)

\begin{tabular}{|c|c|c|c|c|}
\hline $\begin{array}{l}\text { Company's } \\
\text { name }\end{array}$ & Country & Activity & Notes & Website \\
\hline Smart asset & USA & $\begin{array}{l}\text { Advices } \\
\text { throughout } \\
\text { database (find } \\
\text { best credit, } \\
\text { loan solution } \\
\text { among all } \\
\text { propositions } \\
\text { in the market }\end{array}$ & $\begin{array}{l}\text { Tax, retirement, } \\
\text { bank, account } \\
\text { comparison tool }\end{array}$ & Smartasset.com \\
\hline $\begin{array}{l}\text { Simple } \\
\text { finance }\end{array}$ & Russia & Micro lending & $\begin{array}{c}\text { Asset-based loans, } \\
\text { unsecure loans }\end{array}$ & www.ewdn.com \\
\hline
\end{tabular}

have also been essential and probably the most important was the Millennium generation taking their place in the labour and consumer markets. The incumbent bankers disregarded them to focus on more affluent baby-boomers, particularly in asset management services. What the banks did not anticipate is that Millennials are not individually affluent yet but that they are on the way to being the largest demographic group and as a group they hold over $\$ 1$ trillion in wealth (Pitchbook). ${ }^{2}$ This group is not interested in investing in active management funds and having costly financial advisors; they want passive management funds that can be monitored through their mobile phone. What is even of more impact is that the older generations learn to trust technologies that are embraced by the Millennials, so disregarding this generation exposes them to losing their senior relations.

A second insight is that according to some sources of the seven service categories of FinTechs, the most highly funded (Venture Scanner 2019) are lending to consumers and to businesses, (meaning small- and medium-sized enterprises, SMEs). Most of this is based on the peer-topeer business model thus constructing links between borrowers and investors. Some of the FinTechs in this space are co-lending with banks and loan criteria vary across companies, but most want to avoid the classic credit scoring criterion in favour of seeking the highest potential borrowers and the most interesting personal projects. Based on keeping a low operating cost, these FinTechs can offer lower rates to borrowers and higher returns to lenders or investors. This insight is saying that crowdfunding is in a highly relevant position within FinTechs. 
The third insight, as anticipated, is that banks have departed from their original antagonistic view of FinTechs to start finding potential in them as start-up venture opportunities and, more importantly, as resources for internal projects to make their operation more responsive, secure, compliant and efficient (EY 2018; Lee and Shin 2018). Typically, they look at FinTechs to help them reduce operational costs, provide more personalized services through data, and respond to customer behaviour changes. As a result of this, FinTechs have extended their role from retail customer facing to the back office or middle office of banks. Although it is mentioned above that alternative lending is the most funded domain, this can be contested based on the massive resources that are increasingly going into security and privacy initiatives (Gai et al. (2018), citing Gartner, says that the cybersecurity market reached $\$ 75$ billion in 2015 and is projected to reach $\$ 170$ billion by 2020 ; a significant share of this will go to financial services).

Finally, it has been said that in the UK, following the 2007-2008 financial crisis and the tarnished image with which established banks came out of it, the regulators proactively promoted FinTechs in the hope that challenger banks would emerge from them. And in effect this did happen as several challenger banks have emerged (e.g., Monzo, Metro) but their real impact on the market concentration has been marginal with the five big banks still firmly in control. What is even more disappointing is that some of these challenger banks have had to have their business models closely scrutinized by the banking supervisors under suspicion of adopting aggressive lending practices and even manipulating of balance sheets to avoid increased demand for fresh regulatory capital (FT 2019). It is hoped that the implementation of open banking supported by regulations such as Payment Services Directive 2 (PSD2) will enable FinTechs and the most agile and forward-looking mainstream banks to offer more API-enabled services and thus change the oligopolistic structure of the banking business. Traditional banks will not go away but they will most likely become a component of a more fragmented industry in the form of a network of hyperspecialists (Malone et al. 2011).

This evolution of the evolving relationship of banks and FinTechs is summarized in Fig. 11.4. 


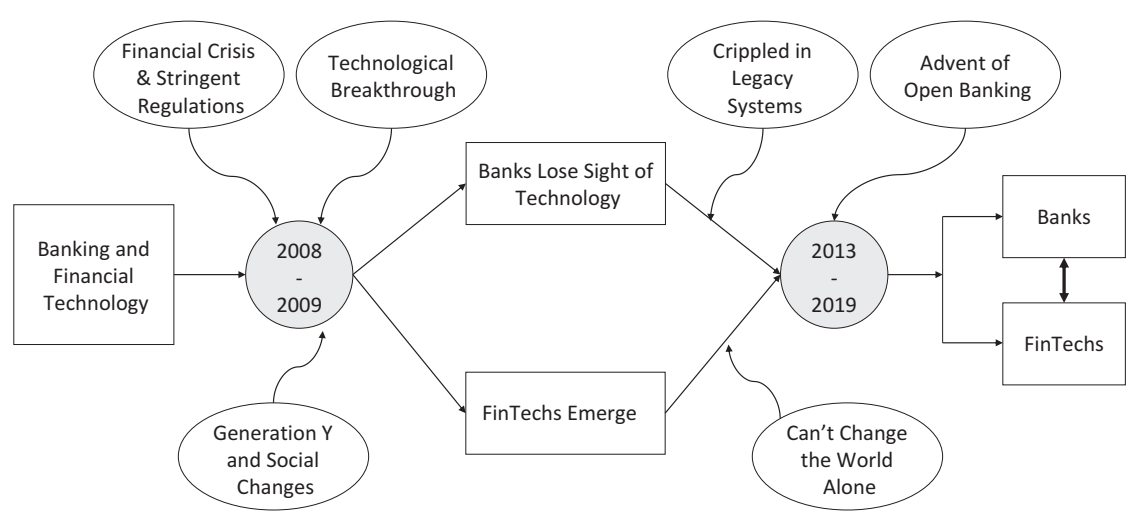

Fig. 11.4 Evolution of the relationship between banks and FinTechs

So, returning to the research question, Why did FinTechs emerge as an industrial sector, independent of banking? A combination of factors happening nearly simultaneously led banks to get distracted from the transformations that were happening around them. Just as the banks were looking inside their own organization to deal with the severe regulatory changes being imposed upon them as a result of the Great Recession, bankers did not perceive the importance that new technologies such as the smartphone were having, nor did they understand the cultural changes that were starting to happen with the coming of age of Gen-Y.

The effect of the smartphone and thus accessibility to devices of a mass market of relatively low income individuals, combined with the lowering of barriers to entry into the banking business of agile entrepreneurs that came with the maturing of cloud computing, enabled FinTech companies to roar into activity.

What encouraged entrepreneurs to move into the multiple banking services domains was the fact that they could detect a great number of underserved banking customers, with a young mindset, to whom they could approach with a narrow service offering driven by technology. That the offering was narrow meant that investment in developing application was relatively low; and the fact that the market was already there meant that cash flow would start coming in quickly. The combination of these 
two factors meant that the amount of working capital required was relatively low.

The fact that the FinTech companies developed relatively focused service offerings within a far reaching service industry as is banking, and that their services are enabled by a large spectrum of technologies that either emerged or matured in the second half of the last decade when this sector was emerging, has led the FinTech sector to encompass a large number of companies with quite different configurations. The framework presented in Table 11.1 as a double-entry table, with seven service-offering domains in one dimension, and over ten technology categories in the other, helps to understand how the sector is organized and where each company plays.

\section{Conclusions}

In summary this research has found that, distracted by the 2007-2008 crisis and its immediate regulatory changes, the banking industry lost sight of the technological breakthroughs and social changes that were happening around it. As a result, after decades of having been a driver and leader for technological change, the industry left windows wide open for nimble companies based on ground-breaking technologies to emerge and 'eat its lunch'.

It is extraordinary that in such a closely regulated industry as banking, these FinTech entrepreneurs could have found gaps in regulations to eat away at some of the most profitable icing on the banking industry's cake. It is also extraordinary that in such a short period of time FinTechs could open into so many different business domains, enabled by the emerging of such an unprecedented number of different game-changing technologies.

The FinTechs managed this feat with little capital in comparison with the deep pockets of the institutions they were outpacing. They achieved this precisely by focusing on niches where the market was already there and waiting for a solution. So, in a way, it was more a pull by social changes than a push by the FinTechs (this is quite different from other areas of technology-based entrepreneurship where the pioneers created a 
market). However, FinTechs should not become complacent as regulation is creeping in. Approximately one-third of the FinTech business in the Eurozone is not regulated, but going forward, FinTechs should count on the fact that banking regulations will move further into their space.

Crowdfunding and other forms of alternative finance occupy a position of relevance within the Fin Tech sector and together have the greatest fraction of investment as compared to the other six business domains included in the FinTech industrial organization framework. Clearly banks have great difficulty in financing the SME segment, where its traditional credit scoring techniques are not appropriate. There is, thus, a promising opportunity for crowdfunding to grow in this space.

Banks have found it hard to keep up as selecting a new technology that will drive its processes is no minor decision for a bank and in times when so many technologies are emerging, it is hard to predict which will be the winning ones. This is not a level field: Clearly banks as incumbents have far more to lose than FinTechs so the question we need to ask ourselves is this: Do extant strategy-technology alignment models apply to banks in times of so much disruption? Banks need to address this issue.

This review of the FinTech sector as a framework to give context to the theme of crowdfunding that is the focus of the rest of this book, is necessarily generic and bridges across the different markets. But clearly the process of emerging of the FinTech sector and the evolution of its relationship to banks, as synthesized in the process described in Fig. 11.4, will change from market to market. As a result of the stage of economic development, the regulatory environment, the quality of the technological infrastructure, the different attitudes towards the financial sector, and many others, the FinTech sector has evolved differently in each market. There is scope to do comparative analyses of this evolution between markets and thus arrive at a more granular knowledge on its evolution.

Finally, another question for future research is why, despite the advent of the FinTech sector with all its diverse set of players, has the market structure in terms of market control by a small number of traditional players, remained essentially unchanged. Will open banking be the answer to this problem? 


\section{Notes}

1. OECD (2003, pp. 65-66) finds that financial intermediation organizations 'are intensive users of information and thus have the greatest scope to benefit from ICT.

2. https://pitchbook.com/news/articles/blend-becomes-latest-fintechstartup-to-bank-a-mega-round-in-2019

\section{References}

Ambrust, M., Fox, A., Griffith, R., Joseph, A. D., Katz, R., Konwinski, A., Lee, G., Patterson, D., Rabkin, A., Stoica, I., \& Zaharia, M. (2010, April). A View of Cloud Computing. Communications of the ACM, 53(4), 50-58. https://doi.org/10.1145/1721654.1721672.

Arner, D. W., Barberis, J., \& Buckley, R. P. (2017). FinTech, RegTech, and the Reconceptualization of Financial Regulation. Northwestern Journal of International Law and Business, 37(3), 371-382.

Barkhuus, L., \& Polichar, V. E. (2011, August). Empowering Through Seamfulness: Smart Phones in Everyday Life. Journal Personal and Ubiquitous Computing, 15(6), 629-639. https://doi.org/10.1007/s00779-010-0342-4.

Boonsiritomachai, W., \& Pitchayadejanant, K. (2017). Determinants Affecting Mobile Banking Adoption by Generation Y Based on the UTAUTM Modified by the TAM Concept. Kasetsart Journal of Social Science. https:// doi.org/10.1016/j.kjss.2017.10.005.

Chen, Y. (2018). Blockchain Tokens and the Potential Democratization of Entrepreneurship and Innovation. Business Horizons, 61(4), 567-575.

Claessens, S., Frost, J., Turner, G., \& Zhu, F. (2018). Fintech Credit Markets Around the World: Size, Drivers and Policy Issues. BIS Quarterly Review, September, pp. 29-49.

Clayton, T., \& Waldron, K. (2003). E-Commerce Adoption and Business Impact, A Progress Report, in Economic Trends, ICT and Economic Growth: Evidence from OECD Countries, Industries and Firms. OECD Publications.

Cotton, I. W., \& Greatorex, F. S. (1968). Data Structures and Techniques for Remote Computer Graphics. Proceedings of the AFIPS '68 (Fall, Part I) Joint Computer Conference, December 9-11, San Francisco, California, pp. 533-544. https://doi.org/10.1145/1476589.1476661. 
Dorfleitner, G., Hornuf, L., Schmtt, M., et al. (2017). Definition of FinTech and Description of the FinTech Industry. In G. Dorfleitner, L. Hornuf, M. Schmitt, \& M. Weber (Eds.), FinTech in Germany. Cham: Springer International Publishing.

Duan, L., \& Da, X. (2012). Business Intelligence for Enterprise Systems: A Survey. IEEE Transactions on Industrial Informatics Information, 8(3), 679-687.

European Central Bank. (2016). ECB Banking Supervision: SSM Priorities 2016 [online]. Retrieved from https://www.bankingsupervision.europa.eu/ecb/ pub/pdf/publication_supervisory_priorities_2016.en.pdf?024a0072 fe923441556e5bba7251dd6d.

European Commission. (2014). Investment Services and Regulated Markets (MiFID 1 \& MiFID 2). Retrieved June 2, 2019, from https://ec.europa.eu/ info/law/markets-financial-instruments-mifid-ii-directive-2014-65-eu_en.

European Commission. (2015). Payment Services (PSD 2)-Directive (EU) 2015/2366. Retrieved June 2, 2019, from https://ec.europa.eu/info/law/ payment-services-psd-2-directive-eu-2015-2366_en.

EY. (2018). ASEAN FinTech Census 2018. Retrieved June 19, 2019, from https://www.ey.com/Publication/vwLUAssets/EY-asean-fintech-census2018/\$FILE/EY-asean-fintech-census-2018.pdf.

Financial Times. (2019). BoE Raises Alert Over 'Aggressive’ New Lenders, June 16. Gai, K., Qiu, M., \& Sun, X. (2018). A Survey on Fintech. Journal of Network and Computer Applications, 103, 262-273.

Griffiths, P. D. R. (2003). A Literature Review: Converting Information Technology Investments into Shareholder Value in Financial Services Organisations. Henley Working Papers, HWP 0315, ISBN. 1861811780.

Griffiths, P. D. R. (2005). The Application of Market Power Theory as a Value Driver for Information Technology Investment Decisions: A Study of Six Chilean Banks. Doctoral thesis, Henley Management College/Brunel University.

Haddad, C., \& Hornuf, L. (2019). The Emergence of the Global Fintech Market: Economic and Technological Determinants. Small Business Economics, 53(1), 81-105.

Hawlitschek, F., Notheisen, B., \& Teubner, T. (2018). The Limits of Trust-Free Systems: A Literature Review on Blockchain Technology and Trust in the Sharing Economy. Electronic Commerce Research and Applications, 29, 50-63. Kotarba, M. (2016). New Factors Inducing Changes in the Retail Banking Customer Relationship Management (CRM) and Their Exploration by the Fintech Industry. Foundations of Management, 8. ISSN 2080-7279. https:// doi.org/10.1515/fman-2016-0006. 
Kumar, A., Nair, A., Parsons, A., \& Urdapiletta, E. (2006). Expanding Bank Outreach through Retail Partnerships: Correspondent Banks in Brazil. World Bank Working Papers, https://doi.org/10.1596/978-0-8213-6702-5

Lacasse, R. M., Lambert, B. A., Osmani, E., Couture, C., Roy, N., Sylvain, J., \& Nadeau, F. (2016). A Digital Tsunami: Fintech and Crowdfunding. Proceedings of International Scientific Conference on Digital Intelligence, April 4-6, UQAR, Quebec, Canada.

Lee, I., \& Shin, Y. J. (2018). Fintech: Models, Investment Decisions, and Challenges. Business Horizons, 61, 35-46. https://doi.org/10.1016/j.bushor. 2017.09.003.

Leong, C., Tan, B., Xiao, X., Tan, F. T. C., \& Sun, Y. (2017). Nurturing a Fintech Ecosystem: The Case of a Youth Microloan Startup in China. International Journal of Information Management, 37, 92-97.

Lundstrom, M. (2003). Moore's Law Forever? Science, 299(5604), 210-211. https://doi.org/10.1126/science.1079567.

Malone, T. W., Laubacher, R., \& Johns, T. (2011). The Age of Hyperspecialisation. Harvard Business Review, 89, 56-65.

McAfee, A., \& Brynjolfsson, E. (2017). Machine Platform Crowd: Harnessing our Digital Future. New York: Norton.

McKeen, J. D., \& Smith, H. A. (1996). Assessing the Value of Information Technology: A Focus on Banking and Insurance. Working Paper \#94-27, Queens University.

Naim, M. (2013). The End of Power. New York: Basic Books.

OECD. (2003). ICT and Economic Growth: Evidence from OECD Countries, Industries and Firms. OECD Publications.

Palazzeschi, E. (2018) Fintech: Why and What Is in the Regulatory Pipe. Presentation at Fintech Conference, EM-Normandie \& Oxford Fintech \& Smart Law Society, March 15.

Puschmann, T. (2017). Fintech. Business \& Information Systems Engineering, 59(1), 69-76. https://doi.org/10.1007/s12599-017-0464-6.

Rimal, B. P., Choi, E., \& Lumb, I. (2009). A Taxonomy and Survey of Cloud Computing Systems. Proceedings of the 2009 Fifth International Joint Conference on INC, IMS and IDC, August 25-27, Seoul. https://doi. org/10.1109/NCM.2009.218.

Rosingh, W., Seale, A., \& Osborn, D. (2001). Why Banks and Telecoms Must Merge to Surge. Strategy+Business (Technical \& Innovation, Q2 2001, Issue 23). Retrieved June 22, 2019, from https://www.strategy-business.com/ article $/ 17163$ ? gko $=4 \mathrm{cda} 6$. 
Roumani, Y., Nwankpa, J., \& Roumani, Y. (2016). Examining the Relationship Between Firm's Financial Records and Security Vulnerabilities. International Journal of Information Management, 36(6), 987-994.

Schmitt, M. G., \& Gautam, T. (2016). Transformation of Banking Institutions: Comparing Germany and India. In H. Ellermann, P. Kreutter, \& W. Messner (Eds.), The Palgrave Handbook of Managing Continuous Business Transformation, (pp. 151-171). Palgrave-Macmillan.

Shneor, R., \& Munim, Z. H. (2019). Reward Crowdfunding Contribution as Planned Behavior: An Extended Framework. Journal of Business Research, 103, 56-70.

Shuttlewood, P., Volin, M., \& Wozniak, L. (2016). Global fintech investment growth continues in 2016 driven by Europe and Asia, accenture study finds. https://newsroom.accenture.com/news/global-fintech-investment-growthcontinues-in2016-driven-by-europe-and-asia-accenture-study-finds.htm.

Smolan, R., \& Erwitt, J. (2012). The Human Face of Big Data. Sausalito, CA: Against All Odds Productions.

Tammas-Hastings, D. (2017) The Exploding Popularity of RegTech. LSE Review. Retrieved December 12, 2018, from http://blogs.lse.ac.uk/businessreview/2017/07/07/the-exploding-popularity-of-regtech/.

Venture Scanner. (2019). Fintech Q1 Update [Online]. Retrieved June 3, 2019, from http://insights.venturescanner.com/category/financial-technology/.

Waldrop, M. M. (2016). The Chips Are Down for Moore's Law: The Semiconductor Industry Will Soon Abandon Its Pursuit of Moore's Law. Nature, 530, 144-147. https://doi.org/10.1038/530144a.

Zavolokina, L., Dolata, M., \& Schwabe, G. (2016). The FinTech Phenomenon: Antecedents of Financial Innovation Perceived by the Popular Press. Financial Innovation, 2(1), 1-16.

Ziegler, T., Shneor, R., Garvey, K., Wenzlaff, K., Yerolemou, N., Zhang, B., \& Hao, R. (2018). Expanding Horizons: The 3rd European Alternative Finance Industry Report. Cambridge: Cambridge Centre for Alternative Finance. 
Open Access This chapter is licensed under the terms of the Creative Commons Attribution 4.0 International License (http://creativecommons.org/licenses/ by/4.0/), which permits use, sharing, adaptation, distribution and reproduction in any medium or format, as long as you give appropriate credit to the original author(s) and the source, provide a link to the Creative Commons licence and indicate if changes were made.

The images or other third party material in this chapter are included in the chapter's Creative Commons licence, unless indicated otherwise in a credit line to the material. If material is not included in the chapter's Creative Commons licence and your intended use is not permitted by statutory regulation or exceeds the permitted use, you will need to obtain permission directly from the copyright holder.

(c) 